\title{
STUDI PENGARUH SUSCEPTIBILITY TO GLOBAL CONSUMER CULTURE (SGCC) TERHADAP MINAT BELI SEPATU SECARA ONLINE PADA GENERASI MILLENIALS
}

\author{
Bekti Pradina Sari ${ }^{1}$ \\ Harry Soesanto ${ }^{2}$ \\ Susilo Toto Raharjo ${ }^{3}$ \\ 1,2,3 Master of Management, Faculty of Economics and Business, Diponegoro \\ University
}

\begin{abstract}
ABSTRAK
Pada saat ini terdapat fenomena unik di kalangan Gen Y ketika teknologi membuat segalanya menjadi lebih mudah, yaitu terjadinya pergeseran perilaku dan pola berbelanja offline menjadi online.Fakta bahwa Pasar E-commerce ini begitu diminati, memberikan dampak yang baik bagi pelaku bisnis dan konsumen, dimana konsumen cenderung membeli barang branded melalui internet secara online di website E-commerce, Website yang akan dijadikan objek adalah Zalora. Penelitian ini mengacu pada penelitian terdahulu, menggunakan variabel social prestige, Internet technology readiness, Quality perception, dan Brand credibility, untuk mengukur pengaruhnya terhadap Susceptibility to Global Consumer Culture (SGCC) dan minat pembelian online konsumen. Objek pada penelitian ini adalah Generasi millenials dengan skala umur 18-35 tahun yang merupakan pengguna website E-commerce khususnya Zalora, yang tersebar di Jakarta, Semarang dan Surabaya. Metode analisis pada penelitian ini menggunakan Structural Equation Model (SEM). Temuan penelitian ini adalah terdapat pengaruh yang signifikan pada variabel social prestige dan internet technology readiness terhadap SGCC dan SGCC memberikan pengaruh signifikan terhadap minat beli konsumen.
\end{abstract}

Kata Kunci: status sosial, kesiapan teknologi internet, kepercayaan merek, persepsi kualitas, kecenderungan budaya konsumen atas merek global, minat pembelian

\section{PENDAHULUAN}

Generasi millenials atau biasa dikenal juga dengan generasi $Y$ adalah kelompok demografi setelah Gen X. Penggolongan Generasi ini ummnya 
ditentukan oleh awal tahun kelahiran. Penggolongan Generasi $Y$ terbentuk bagi yang lahir pada awal 1980-an, 1990-an hingga awal 2000-an sebagi akhir kelahiran. Generasi Milenial ini kadang juga disebut sebagai "Echo Boomers" karena adanya peningkatan yang besar pada tingkat kelahiran 1980-an dan 1990-an. Berbeda dengan generasi sebelumnya, Generasi millenials lahir dan tumbuh di ingkungan yang serba digital, dimana handphone, televisi berwarna dan jaringan internet sudah diperkenalkan.Oleh karena itu kehidupan generasi ini tidak dapat dipisahkan dari teknologi, baik smartphone, tablet, televisi atau personal computer (PC).

Alvara Research Center telah membuktikan bahwa pada akhir tahun 2016 konsumsi internet generasi millenial atau Gen $Y$ di Indonesia cukup tinggi yaitu mereka dapat menghabiskan waktu 7 jam lebih per-hari dibandingkan dengan Gen $X$ yang hanya berkisar 3-4 jam per-hari. Hal ini didukung pula oleh hasilriset APJII (Asosiasi Penyelenggara Jasa Internet Indonesia) yang meneliti tentang pengguna internet di Indonesia, yaitu pada tahun 2016 terdapat sekitar 132,7 juta pengguna dan naik menjadi 143,26 juta pengguna di tahun 2017. Penduduk Pulau Jawa mendominasi sebesar $58 \%$ pengguna internet aktif apabila dibandingkan dengan daerah lain, dan dari total seluruh pengguna internet generasi millenial terlihat sangat mendominasi di angka 49,52\%.

Ada fenomena unik di kalangan Gen Y ketika teknologi membuat segalanya menjadi lebih mudah, yaitu terjadinya pergeseran perilaku dan pola berbelanja offline menjadi online. Hal inilah yang kemudian melahirkan sejarah berkembangnya bisnis E-Commerce. E-Commerce merupakan kegiatan jual beli barang atau transmisi dana atau data melalui jaringan internet. Generasi millenial atau Gen $Y$ dengan kisaran usia 25-35 tahun menempati urutan teratas pada angka $50 \%$ penikmat E-commerce terbanyak apabila dibandingkan dengan Gen Z dengan kisaran usia 15-24 tahun, terhitung sebanyak 31\%, Gen X dengan kisaran usia 3544 tahun pada angka $16 \%$ dan terakhir generasi Baby Boomers pada kisaran usia lebih dari 45 tahun sebanyak $2 \%$ menurut hasil survei marketeers.com. Menurut http://www.prastitan.web.id produk yang menempati posisi pencarian tertinggi dan sangat sering di konsumsi dan di beli secara online adalah kosmetik, produk fashion, peralatan rumah tangga, produk elektronik dan gadget. Produk Fashion terlaris mencangkup apparel, hijab atau kerudung, sepatu, tas, dan kaca mata. Penelitian ini akan membahas mengenai kecenderungan konsumen terhadap minat beli produk Sepatu beremerek global di website E-commerce, Zalora.

Zalora didirikan pada tahun 2011, merupakan bagian dari Global Fashion Group terkemuka di dunia. Hingga saat ini, telah beroperasi di sebanyak 27 negara. Zalora di Indonesia didirikan pada tahun 2012 dan merupakan perusahaan e-commerce online yang memiliki perkembangan terpesat di Asia. Pada awal tahun 1990-an terdapat sebuah konsep yang disebut dengan budaya konsumen dalam membeli 
produk global, yang biasa disebut dengan Global Consumer Culture (GCC). Global Consumer Culturesecara spesifik didefinisikan sebagai kecenderungan konsumen yang berkaitan dengan hal-hal yang berbau global bermula dari merek, kategori produk, dan aktivitas konsumsi (Terpstra and David, 1991). Kecenderungan dalam memilih produk bercita rasa global kemudian dinilai melalui perilaku konsumen yang memiliki latar belakang budaya yang berbeda dapat memiliki kesamaan dalam mempersepsikan merek global (Keillor et. Al., 2001).

Menurut Zhou dan Poon (2008)mengenai karakteristik konsumen, ada saat dimana dia secara terpendam dan tersembunyi memiliki keinginan atau kecenderungan untuk memilih, memakai dan mengkonsumsi global brand disebut dengan kecenderungan budaya konsumen terhadap merek global atau Susceptibility to Global Consumer Culture(SGCC). Konsep kecenderungan budaya konsumen terhadap merek global ini pertama kali digagas pada tahun 2008 dimana dipengaruhi oleh kesesuaian norma sosial atau conformity of social norms, persepsi kualitas. Kemudian model konsep SGCC ini dilanjutkan oleh Yue, 2008 dan dalam penelitiannya menemukan bahwa kesiapan terhadap adanya teknologi internet adalah salah satu dimensi baru SGCC. Dimensi lainnya diungkapkan oleh Merino (2015) yaitu Social Prestige, lebih jauh diungkapkan pula oleh hasil penelitian Ozsomer dan Altaras (2008) adalah brand credibility. Penelitian ini bertujuan untuk mempelajari dan menganalisis lebih lanjut. Perumusan masalah pada penelitian ini adalah untuk mengetahui pengaruh Susceptibility to Global Consumer Culture (SGCC) Terhadap Minat Beli Sepatu Di Zalora Pada Generasi Millenials.

\section{TELAAH PUSTAKA}

Globalisasi dapat terjadi dan berkembang dengan cepat tidak luput dari adanya perkembangan pada bidang teknologi, informasi dan komunikasi. Contoh sederhana adalah adanya kemudahan dalam mengakses internet kapn saja dan dimana saja, seluruh manusia dibelahan bumi manapun akan dapat mengakses berita dan isu terkini dengan mudah dan cepat. Hal ini memungkinkan terjadinya interaksi antar masyarakat secara luas yang pada akhirnya akan saling mempengaruhi satu sama lain seperti, pengaruh terhadap budaya, kebiasaan sehari-hari, cara berpakaian, pola pikir dan sebagainya.

Munculnya pasar bebas ditingkat global seperti AFTA (Asean Free Trade Area) dan AFLA (Asean Free labour Area) dimana kesepakatan ini dibentuk oleh banyak negara di ASEAN untuk menciptakan suatu zona perdagangan bebas. Hal ini menandakan bahwa semakin mudahnya akses perdagangan bebas dan masuknya merek-merek (brand) global ke dalam pasar Indonesia. Menurut Kotler (2005) merek didefinisikan sebagai "name, term, sign symbol (or a combination of 
these) that indentifies the makes or seller of the products", dalam terjemahan yaitu nama, istilah atau sebutan, atau lambang (atau kombinasi diantaranya) yang mengidentifikasikan penjual suatu produk.

\section{Susceptibility to Global Consumer Culture (SGCC)}

Susceptibility to Global Consumer Culture (SGCC) atau kecenderungan budaya konsumen terhadap merek global dapat didefinisikan sebagai variasi karakteristik atau perbedaan sifat-sifat konsumen pada satu individu ke individu lainnya yang tercermin pada suatu keinginan atau kecenderungan dalam menggunakan sesuatu yang bermerek atau bercita rasa global. Sifat ini pada umumnya akan ditandai dengan adanya kebebasan budaya dan selanjutnya akan didorong oleh karakteristik individual konsumen (Zhou et. al. 2008).

\section{Social Prestige}

Seperti yang telah umum kita ketahui, Prestige biasanya dikaitkan dengan kedudukan atau status sosial yang berkaitan dengan pekerjaan atau jabatan atau keterampilan atau kebanggan tertentu karena terlahir pada keluarga yang memiliki posisi sosial menengah keatas. Wong \& Zhou (2005) mengemukakan bahwakonsumen yang mengkonsumsi atau membeli produk dengan merek global adalah konsumen yang ingin menunjukkan sinyal akan seberapa besar kekayaan, kekuasaan, dan status mereka.

\section{Internet Technology Readiness}

Pasuraman (2000) mengemukakan bahwa Technology readiness merupakan kesiapan dalam menerima informasi dan teknologi dalam suatu sistem. Dalam penelitiannya dijelaskan tentang skala untuk mengukur tingkat kesiapan dalam menggunakan teknologi melalui Technologi Readiness index (TRI). Technology readiness dapat dibedakan menjadi 4 kelompok yaitu: optimism, innovativeness, discomfort, dan insecurity. Optimism atau optimisme digambarkan sebagai keyakinan terhadap teknologi untuk meningkatkan kontrol, fleksibilitas atau keluwesan dan efisiensi dalam menerima informasi. Innovativeness digambarkan sebagai kecenderungan untuk menjadi yang pertama dalam menggunakan teknologi baru. Discomfort atau ketidaknyamanan merupakan adanya rasa kurang nyaman serta berkurangnya kontrol terhadap teknologi. Insecurity atau ketidakamanan adalah timbulnya rasa tidak percaya dari segi keamanan dan privasi serta timbulnya perasaan skeptis tentang adanya peningkatan teknologi.

\section{Quality Perception}

Persepsi konsumen pada suatu produk sangatlah penting karena akan mempengaruhi minat beli konsumen pada akhirnya. Menurut Jin dan Yong (2005), 
Kualitas adalah salah satu elemen penting untuk pengambilan keputusan pembelian para kosumen, karena konsumen akan membandingkan beberapa alternatif kualitas dengan harga yang ditawarkan dalam satu kategori. Menurut Rao dan Ruekert (1994) persepsi kualitas dapat dibagi menjadi dua yaitu secara objektif dan subyektif. Seacara Objektif Hal - hal yang dapat mempengaruhi dan mengevaluasi kualitas produk suatu merek antara lain adanya bauran pemasaran, perbedaan harga, tempat Negara asal merek, garansi dan advertising. Bila dilihat dari segi objektif nama-nama merek juga berfungsi sebagai sinyal kualitas yang tidak dapat diamati .oleh karena itu penilaian tentang kualitas suatu merek dapat diperoleh secara langsung berdasarkan pengalaman terdahulu dengan produk tersebut atau hanya dengan mendengarkan atau mengamati produk tersebut.

\section{Brand Credibility}

Kredibilitas secara luas dapat didefinisikan kepercayaan terhadap suatu produk beserta informasi atau pesan yang terkandung pada merek tersebut yang membuat konsumen menaruh kepercayaan terhadap apa yang telah dijanjikan oleh merek tersebut (Erdem and Swait, 2015) .Dua aspek Kredibilitas Merek yang palingutama adalah kepercayaan dan Keahlian. Kepercayaan yang dimaksud adalah apakah suatu perusahaan bersedia untuk memberikan apa yang telah dijanjikan dan keahlian disini adalah apakah perusahaan tersebut sudah mampu memenuhi apa yang telah dijanjikan (Baek and King, 2011).

\section{Purchase Intention}

Purchase Intention atau niat membeli adalah keinginan konsumen untuk membeli produk atau jasa. Niat merupakan aspek yang akan mempengaruhi minat beli konsumen setelah melakukan proses evaluasi terhadap suatu produk atau jasa. Banyak sekali factor yang pada akhirnya dapat mempengaruhi niat konsumen pada saat memilih produk dan keputusan akhir pembelian bergantung pada niat konsumen yang ditunjang oleh beberapa factor eksternal (Keller, 2001).

\section{Gambar 1}

Kerangka Penelitian

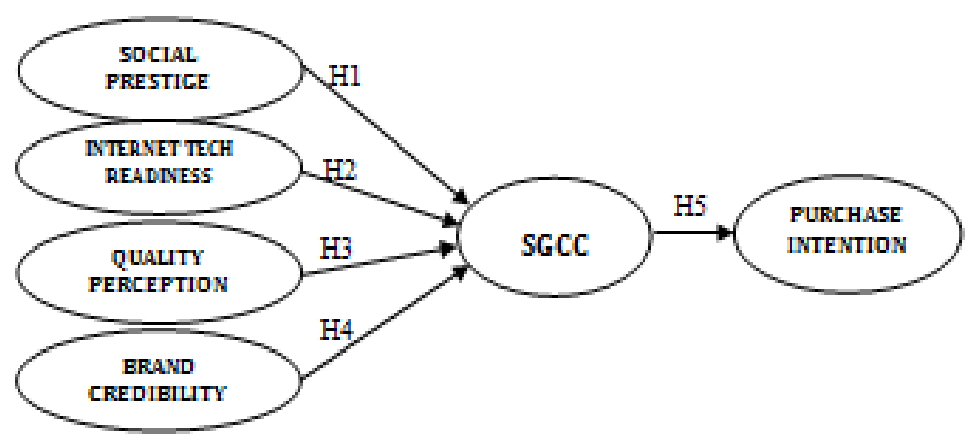




\section{Hipotesis Penelitian}

$H_{1}$ : Social prestige memberikan pengaruh positif terhadap Susceptibility to Global Consumer Culture (SGCC)

$\mathrm{H}_{2}$ : Internet technology readiness atau kesiapan penggunaan teknologi Internetmemberikan pengaruh positif terhadapSusceptibility to Global Consumer Culture (SGCC)

$H_{3}$ : Quality perception atau persepsi kualitas memberikan pengaruh positif terhadap Susceptibility Global Consumer Culture (SGCC)

$\mathrm{H}_{4}$ : Brand credibility atau kredibilitas merek memberikan pengaruh positif terhadap Susceptibility Global Consumer Culture (SGCC)

$H_{5}$ : Susceptibility Global Consumer Culture (SGCC) memberikan pengaruh positif terhadap purchase intention atu minat beli konsumen.

\section{METODE PENELITIAN}

Jumlah Sampel yang akan diambil adalah berkisar 151 sampel. dengan daerah perwakilan yang memiliki kepadatan penduduk tertinggi berdasarkan sensus penduduk 2016, yaitu Daerah Khusus Ibukota Jakarta, Jakarta, Ibukota propinsi Jawa timur, Surabaya dan Ibukota Propinsi Jawa tengah, Semarang. Penelitian ini menggunakan Structural Equation Model (SEM) sebagai model dan pengujian hipotesis dan diproses menggunakan software IBM AMOS 22.

\section{ANALISIS DATA DAN PEMBAHASAN}

\section{Tabel 1}

Regression Weight Structural Equation Model

\begin{tabular}{lllrrrrl}
\hline & & & Estimate & S.E. & C.R. & P & Label \\
\hline SGCC & $<--$ & SP &, 559 &, 240 & 2,326 &, 020 & par_11 \\
SGCC & $<--$ & ITR &, 611 &, 250 & 2,443 &, 015 & par_12 \\
SGCC & $<---$ & QP &,- 256 &, 396 &,- 645 &, 519 & par_13 \\
SGCC & $<---$ & BC &,- 068 &, 101 &,- 669 &, 503 & par_14 \\
PI & $<--$ & SGCC & 1,116 &, 125 & 8,943 & $* * *$ & par_15 \\
\hline
\end{tabular}

Berdasarkan analisis data yang telah dilakukan maka dapat ditarik kesimpulan sebagai berikut: 
$\mathrm{H}_{1}$ : Social prestige memberikan pengaruh positif terhadap Susceptibility Global Consumer Culture (SGCC) dapat diterima.

Nilai critical ratio (CR) sebesar 2,326 dengan nilai probablitas sebesar 0,020. Ditinjau dari nilai loading factor, indikator yang memiliki nilai tertinggi ialah SP3,disusul oleh SP2, SP1 lalu terakhir adalah SP4, dengan masing masing nilai loading faktor adalah 0,866, 0,837, 0,683 dan 0,604. Dimana indikator tertinggi yaitu memakai Sepatu bermerek dapat meningkatkan rasa percaya diri, selanjutnya yaitu membeli sepatu bermerek menambah nilai prestige dengan nilai, kemudian indikator selanjutnya mengukur tentang seberapa up to date atau fashionable.

$\mathrm{H}_{2}$ : Internet technology readiness atau kesiapan penggunaan teknologi internet memberikan pengaruh positif terhadap Susceptibility Global Consumer Culture (SGCC) dapat diterima.

Nilai critical ratio (CR) 2,443 dengan nilai probablitas 0,015 . Untuk nilai loading factor, indikator yang memiliki nilai tertinggi ialah ITR3, ITR1 lalu terakhir adalah ITR2, dengan masing masing nilai loading faktor adalah 0,852, 0,820 dan 0,659. Dimana indikator tertinggi yaitu memakai Sepatu bermerek dapat meningkatkan rasa percaya diri, selanjutnya yaitu membeli Sepatu bermerek menambah nilai prestige dengan nilai , kemudian indikator selanjutnya mengukur tentang seberapa up to date atau fashionable

$H_{3}:$ Quality perception atau persepsi kualitas memberikan pengaruh positif terhadap Susceptibility Global Consumer Culture (SGCC) ditolak.

Nilai critical ratio (CR) sebesar -,645 dengan nilai probablitas sebesar 0,000. Hipotesis ini ditolak dapat terjadi karena kemungkinan kesalahan pemilihan indikator, atau adanya kemungkinan pengisian data asal oleh responden.

$\mathrm{H}_{4}$ : Brand credibility atau kredibilitas merek memberikan pengaruh positif terhadap Susceptibility Global Consumer Culture (SGCC) ditolak nilai critical ratio (CR) sebesar -,669 dengan nilai probablitas sebesar 0,503. Hipotesis ini ditolak dapat terjadi karena kemungkinan kesalahan pemilihan indikator, atau adanya kemungkinan pengisian data asal oleh responden.

$\mathrm{H}_{5}$ : Susceptibility Global Consumer Culture (SGCC) atau kecenderungan konsumen untuk membeli brand global memberikan pengaruh positif terhadap purchase intention diterima

Nilai critical ratio (CR) sebesar 8,943 dengan nilai probablitas sebesar 0,503. Ditinjau dari nilai loading factor, indikator yang memiliki nilai tertinggi ialah SGCC3, SGCC2 lalu terakhir adalah SGCC4, dengan masing masing nilai loading faktor adalah $0,739,0,698$, dan 0,642. Dimana indikator tertinggi yaitu merasa tidak 
mempermasalahkan biaya untuk membeli sepatu bermerek global, membeli sepatu bermerek global dapat meminimalisir resiko yang timbul, dan persepsi terhadap barang bermerek global itu sendiri. Untuk indikator SGCC1 pada penelitian ini dihilangkan karena nilai loading faktor $<0.60$.

\section{KESIMPULAN DAN SARAN \\ Kesimpulan}

Berdasarkan hasil penelitian yang telah dilakukan, kesimpulannya adalah sebagai berikut:

1. Social prestige memberikan pengaruh positif terhadap SGCC hal ini dipengaruhi oleh indikator mengenai seberapa up to date dan fashionable barang yang ditawarkan. Semakin up to date dan fashionable barang tersebut maka akan semakin diminati oleh para konsumen, dan menambah nilai jual suatu produk. Indikator selanjutnya yaitu sebagai suatu simbol kekayaan atau kekuasaan, hal ini menunjukkan bahwa membeli sepatu bermerek global dapat menunjukkan tingkat kekayaan dan kekuasaan seseorang, dimana untuk beberapa jenis sepatu tertentu yang bermerek global seringkali mengeluarkan produk Limited editiony ang tentu saja bisa dibilang tidak murah. Hal inilah yang kemudian membuat seseorang merasa bahwa membeli sepatu tertentu dengan edisi terbatas dapat menunjukkan tingkat kekayaan atau status sosial, karena tidak semua orang dapat membeli sepatu yang sama. Indikator selanjutnya adalah berhubungan dengan gengsi, tentu saja membeli Sepatu bermerek global dapat meningkatkan rasa percaya diri dan menambah gengsi si pemakai, hal ini ditunjang dengan seberapa terkenal merek yang dipakai, sebarapa menarik designnya dan seberapa banyak Sepatu ini digunakan oleh suatu golongan atau komunitas tertentu. Karena semakin banyak orang yang menggunakan merek tersebut, maka si pemakai akan semakin bangga dan meningkatkan gengsi si pemakai, dan indikator yang terakhir adalah mengukur gaya hidup.. Hal ini berkaitan dengan membeli Sepatu bermerek global bukan lagi sebagai sesuatu hal yang wah atau luar biasa, melainkan membeli Sepatu bermerek global sudah menjadi lifestyle atau gaya hidup generasi millenials dimana mereka sudah mempersiapkan bujet tertentu khusus untuk membeli sepatu bermerek global.

2. Internet technology readiness memberikan pengaruh positif terhadap SGCC. Hal ini dipengaruhi oleh indikator kemudahan dalam penggunaan, dimana semakin mudah penggunaan atau akses website nya maka akan semakin tinggi kecenderungan sesorang untuk terus menggunakan dan mengakses website tersebut. Indikator yang berpengarung selanjutnya adalah adanya tingkat ketergantungan terhadap internet, hal ini dapat dilihat dari gaya hidup generasi 
millenials yang selalu terhubung dengan jaringan internet setiap harinya, mulai dari bangun tidur hingga waktu ketika mau tidur pada malam harinya. Dan terakhir oleh indikator usefullness bahwa adanya koneksi internet sangat membantu baik dalam kemudahan pembelian barang yang diinginkan ataupun untuk medapatkan informasi.

3. SGCC berpengaruh terhadap purchase intention Hal ini didukung oleh adanya 3 indikator yang berpengaruh yaitu meminimalisir resiko yang, yaitu ketika kita membeli Sepatu bermerek global yang namanya sudah begitu terkenal dimanamana maka hal ini dapat meminimalisir resiko yang timbul, karena kualitas barang yang telah terbukti, serta ketahanan barang dan tentunya ketika barang tersebut banyak digunakan oleh orang lain, maka kita bisa sharing pendapat apakah barang tersebut worth it untuk dibeli. Indikator selanjutnya yang berpengaruh yaitu jumlah biaya yang dikeluarkan, persepsi terhadap global brand, dimana para konsumen sudah menetapkan standar tertentu terhadap barang yang akan mereka dapatkan setelah proses pembelian, yaitu kenyamanan dan kualitas barang yang sudah tidak diragukan lagi ketika membeli Sepatu bermerek global.

\section{Implikasi Manajerial}

Implikasi Manajerial perlu dilakukan oleh E-commerce Zalora yang menawarkan produk Sepatu agar dalam konsep pemasarannya menimbulkan minat beli para online customer.Seperti kita ketahui sebelumnya pada bab pembahasan hasil, bahwa variabel yang memberikan pengaruh langsung dengan nilai tertinggi adalah variabel internet technology readiness, maka adapun saran yang dapat disampaikan adalah:

1. Membuat tampilan website secara sederhana, mengurangi tools dan menambahkan keterangan (informasi) cara penggunaan pada web, sehingga dapat mempermudah seseorang untuk mengakses dan melakukan pembelian walaupun pada kali pertama penggunaan.

2. Sering menawarkan flash sale pada interval waktu tertentu yang tak terduga sehingga customer akan secara berkala untuk membuka website Zalora, juga harus dapat melibatkan pelanggan di sosial media, seperti misal memberikan link untuk share produk favorit melalui instagram, facebook, snapchat dan lain sebagainya.

3. Diharapkan Zalora juga dapat memberikan beberapa informasi yang lengkap tentang review dan detail barang seperti: jenis, bahan atau material barang, pabrik pembuatan, tahun pembuatan dan lisensi barang.

4. Diharapkan pula Zalora selain website e-commerce yang menawarkan berbagai produk juga dapat diselingi dengan menampilkan pula isu isu terkini 
sehingga customer tidak hanya tertarik membeli namun juga dapat melihat informasi dan hal tersebut juga dapat diselingin dengan memberikan jeda berupa iklan, diharapkan hal ini nantinya dapat efektif dalam meningkatkan penjualan.

\section{Keterbatasan Penelitian}

Penelitian ini telah diusahakan dan diljalankan seturut dengan prosedur ilmiah yang berlaku, namun masih terdapat keterbatasan antara lain:

1. Pengambilan sample penelitian ini hanya terfokus pada 3 kota besar saja, yaitu Daerah Khusus Ibukota Jakarta, Ibukota propinsi Jawa timur, Surabaya dan Ibukota Propinsi Jawa tengah, Semarang

2. Variabel yang diteliti hanya 4 jenis varibel yang mempengaruhi SGCC yaitu Social Prestige, Internet technology readiness, Brand Credibility dan Quality perception.

\section{Agenda Penelitian Mendatang}

Hasil serta keterbatasan penelitian yang didapatkan selama penelitian ini berlangsung dapat dijadikan sumber inspirasi bagi peneliti mendatang yang sekiranya akan melakukan pengembangan pada penelitian ini di masa yang akan datang, sehingga perluasan penelitian yang disarankan atas penelitian ini ialah sebagai berikut:

1. Menambah atau mengganti variabel yang memberikan pengaruh terhadap SGCC.

2. Mengganti indikator pada variabel Brand Credibility dan Quality Perception sehingga dapat memberikan kemungkinan gambaran hasil yang signifikan; dan

(3) Memperbanyak jumlah sampel penelitian sehingga mendapat gambaran hasil yang lebih baik.

\section{REFERENSI}

Baek, T.H., and King, K.W. (2011).Exploring the consequences of brand credibility in services.Journal of Services Marketing, Vol. 25, No. 4, pp. 260-272.

Erdem, T.,\&Swait, J. 2015. Brand Credibility, Brand Consideration, and Choice.new York University. Journal of Consumer Research pp 31(1):191

Erdem, T., and Joffre S.,.1998.Brand Equity as a Signaling Phenomenon. Journal of Consumer Psychology, 7 (April),131-57 
Jin, B. and G.S. Yong, 2005.Integrating effect of consumer perception factors in predicting private brand purchase in a Korean discount store context. J. Consumer Market, 22: 62-71.

Keller, K. L.2001. Building customer-based brand equity: creating brand resonance requires carefully sequenced brand-building efforts, Marketing Management, Vol. 10 ,

Kotler, Philip \& Garry Armstrong. 2010. Prinsip-PrinsipPemasaran, Jilid 1 dan 2 EdisiKeduaBelas. Jakarta :Erlangga

Merino, M.,Mazzon, J., \& Isabella, G. 2015. A Model Of Susceptibility to Global Consumer Culture. Bussines Management Journal

Ozsomer, Ays,egül and altaras sellin (2008), Global Brand Purchase Likelihood: A Critical Synthesis and an Integrated Conceptual Framework. Journal of International Marketing, Vol. 16, No. 4, 2008, pp. 1-28.

Rao, A.R., and Ruekert, R.W. (1994).Brand alliances as signals of product quality. Sloan Management Review,Vol. 36, Fall, pp. 87-97.

Yue, Huo.2008.Susceptibility to Global Consumer Culture : Scale Development And Purchase Behaviour Of Shanghai Consumers.

Zhou, L., Teng, L., and Poon, P. (2008). Susceptibility to global consumer culture: a three-dimensional scale. Psychology and Marketing, 25 (4), 336-351.

Zhou, L. \&Poon,P. 2011. Susceptibility to Global Consumer Culture: a CrossCultural Study. 